\title{
Deciding nuclear policy by argument
}

The next step in the British nuclear industry hangs on a public inquiry begun this week. The reasons why this is the wrong way to decide matters of public policy deserve to be more widely understood.

WHILE the post-Christmas pantomime season (men in drag, women dressed as boys) continues to fill the provincial theatres, the UK Department of Energy has provided a comparable event to keep the small village of Snape in Suffolk busy until the Aldeburgh music festival comes around again in the summer. For the public inquiry into the plan to build the first Britain pressurized water reactor (see page 102), which opened this week, will be pantomimic not merely in the sense that it is well rehearsed but also because the chief participants in this long drawn out affair will be required to dissemble. The Central Electricity Generating Board, which wants to build the reactor and eventually to operate it, has a reasonably straightforward objective - to make pressurized water reactors the chief means of generating nuclear energy in the decades immediately ahead; it will find itself required to go along with the assumption underlying the public inquiry that, in spite of the technical assessments of the safety of the proposed reactor which have been carried out in the past several years, others than those directly concerned will have the final say. And many of the objectors at the inquiry, who will no doubt concentrate their arguments on the weakest points in the generating board's case - the stagnation of electricity demand and the increased cost of nuclear reactors - will know that their case will be undermined if they openly declare their true beliefs that nuclear energy is an abomination.

This is the essence of the case that the public inquiry is a waste of time (see Nature 23/30 December 1982, p.672). That assertion is, of course, contentious, as readers' letters yet to be published will demonstrate, but the underlying issues are nevertheless crucial to the proper assessment of new technological projects in democratic countries such as Britain. The British tradition that there should be public inquiries into projects likely to cause an environmental nuisance was formally enshrined in the Town and Country Planning Act of 1947, amended in 1971, from which, however, agriculture and national defence are exempted, as are other publicly owned enterprises. The procedures that bring nationalized industries to public inquiries are different, stemming from the enabling legislation that allows the industry to exist and mandatory if a planning authority should object. In recent decades, ministers with contentious public projects on their hands have sensibly taken the view that public inquiries serve a useful purpose, not least because they give local populations an opportunity to question those responsible about the safety and seemliness of what is proposed.

\section{Costs}

The Sizewell inquiry, however, is different in its character. Deliberately, the Department of Energy has decided that the inquiry should be broad in scope, designed to deal with questions of whether pressurized water reactors are safe and even necessary. One of the intricate issues certain to be raised during the proceedings will be that of whether the Central Electricity Generating Board is on sure ground in its calculation of the costs of producing electricity from various fuels, an issue on which it was criticized by the Monopolies Commission a year ago. In the trade, the inquiry is called "generic" - and the benefits, both for the Department of Energy and the generating board, of a favourable recommendation would be that later plans to build pressurized water reactors might be decided on the nod. While that calculation is probably correct, it leaves out of account the damage that will be done to the quite separate arrangements that exist for making publicly acceptable decisions on such questions - and the high cost of the delay.

The duplication by the inquiry of the parallel arrangements for regulating the use made by the generating board of nuclear reactors is potentially the most damaging. As elsewhere, Britain now has an elaborate system whereby nuclear plants and the operations of the electricity industry in general are supervised by constitutionally independent organizations. Thus licences for the construction and operation of nuclear power stations are issued by the Department of Energy only on the recommendation of the Nuclear Installations Inspectorate, which is maintained by a quite separate organization. The nuclear inspectorate has every incentive to be independent, and in particular to demonstrate its independence from the interests of those who wish either to build or to operate nuclear plants. Its opinion on the safety of the generating board's design, due to be heard towards the end of March, will obviously be important. If that opinion should be negative - at some stage, the inspectors will be asked "So would you recommend that a licence should be issued?" - the question of what the inquiry is for will be raised in the starkest form. If, on the other hand, the opinion is positive but the inspector, Sir Frank Layfield, disagrees, the question will be what the inspectorate itself is for.

Other issues certain to be raised in the months ahead are broader, the place of nuclear power in the British energy economy chief among them. Constitutionally, because British nuclear plants produce only electricity, public utilities such as the generating board have the formal say on what should be done. But the general operations of public utilities are subject to the approval of the Department of Energy (which has historically sought to encourage the use of coal), which can also give directions about capital investment. In the event, the department does not operate in a vacuum, but among other things is subject to a constant stream of advice from influential sources such as the select committees of the House of Commons. While the present government differs from most of its predecessors in not having an energy policy in the sense of not having published a prediction of how much energy will be won from different kinds of fuels in the years ahead, it is unthinkable that it could be diverted from its declared belief in keeping open all options by what is said at Sizewell. But if such a case can be miraculously established, will not the question arise of what parliament is for?

The issue of the cost of nuclear energy is even more tortuous in its constitutional implications. What matters is not the cost of nuclear electricity but that of electricity from whatever mixture of sources the generating boards have at their command. There are circumstances in which the addition of a relatively costly generating plant to a network may be the most economical course, if for example it can operate at more or less full load for most of the time. There is also something in the argument that it may be worth paying something in the way of capital cost for experience with a new kind of machine. There is little doubt that the generating boards (like other British nationalized industries) have in the past been too cavalier about the right to fix the prices charged for their products. Now, fortunately, the British government seems to have woken up to the importance of nationalized industries' prices, and is determined to constrain them. It is, however, hard to see how the Layfield inquiry could reject outright the generating board's economic case without calling into question the continued need for the Department of Energy. And if the inquiry is as daring, will those now planning to put objections to the inquiry then level similar complaints at the generating board's flirtation with windmills?

The absurdity of the Sizewell inquiry thus stems from the way in which broad questions of national and administrative policy are confused with the question of whether people living near the proposed reactor site will be exposed unduly to hazards, or whether an admittedly splendid stretch of coast is being needlessly developed. But are not open government and public accountability desirable objectives? Of course. The snag is that the inquiry now under way is a theatrical diversion from both objectives. 